\title{
Evidence on the prevention of cancer
}

\author{
D. Salas, R Peiró
}

Dirección General de Salud Pública. Conselleria de Sanitat. Valencia.

(General Directorate for Public Health of the Health Department in Valencia)

Área de cáncer y salud pública CSISP-FISABIO

(Area on Cancer and Public Health)

\begin{abstract}
Cancer is one of the main health problems. It includes a set of diseases with multi-causal origins. The tumours with the greatest impact on the health of men are lung, prostate and colorectal cancers, while for women they are breast and colorectal tumours.

The best strategies for preventing cancer are ones based on primary prevention and early diagnosis. It is estimated that about to $80-90 \%$ of cancers are preventable.

As regards primary prevention, there is considerable evidence to suggest that not smoking, regular physical exercise and a diet rich in fruit and vegetables, along with the control of some environmental and occupational risk factors can reduce the incidence of cancer. The early diagnosis of breast, colorectal and cervical cancer is recommended for some groups of the population in a context of organised programs with adequate quality guarantees.
\end{abstract}

Keywords: Neoplasms; Cancer; Primary prevention; Early diagnosis; Straining; Spain; Prisons; Feeding.

Reception: 7-05-2013

Approval: 11-05-2013

\section{INTRODUCTION}

Cancer is one of the leading causes of mortality and morbidity and thus a priority within the health policies. In 2006 there were 98.000 deaths caused by cancer, 61.000 were men and 37.000 women.

Cancer has been the second cause of death in Spain in the last decades, only exceeded by cardiovascular diseases. Since 2005, tumors are the first cause of death in men. As far as incidence is concerned, according to the Spanish records concerning the 19982002 period, among men there were between 321 and 511 cases $/ 100.000$ men, and between 204 and $286 \mathrm{ca}-$ ses/100.000 among women ${ }^{1-2}$. The most common tumors found in men are lung, prostate and colorectal cancer and in women breast and colorectal cancer, and these forms of cancer are the leading causes of death from cancer.

Alike most chronic diseases, cancer has its origin in several causes, such as lifestyle, factors related to working environments and social determinants, which play a major role in the development of health and disease. Therefore the best health promotion strategies to improve the population well-being are those based on prevention and in the development of intersectoral health policies. Diverse institutions such as the World Health Organization (WHO) and the European Union have promoted different initiatives to fight against cancer, such as "Europe Against Cancer". These initiatives have considered prevention as the elective strategy to fight against cancer.

Prevention strategies are based on reducing risk factors (primary prevention) and in the early detection of cancer (secondary prevention). We must also take into consideration that the exposure to all risk factors- both those which we, as individuals, can somewhat modify, such as physical exercise; as well as those which we can not, such as environmental factors- varies according to socio-economic, gender-based and other social aspects, and therefore this entails inequalities in the development of cancer. Whenever possible, primary prevention strategies should be 
prioritized and supported by secondary prevention strategies. Also, strategies must be developed in order to ensure that the whole population benefits from prevention policies and that inequality in exposure and disease development does not occur.

To revise the actions that could be promoted, both from the public policies and from the population itself and individuals, in order to reduce and prevent this health problem, is a broad topic as cancer is not just one disease but a term used to encompass several diseases and thus the factors that are involved in its causes are also numerous.

Within the European context, the guidelines to avoid cancer are gathered together in the "European Code Against Cancer", that analyses the possibility to influence its control by means of primary and secondary prevention strategies. A summary of the main points of the European Code Against Cancer, and the scientific evidence that supports them can be found in this publication ${ }^{3-4}$. The guidelines are compiled in Table 1.

\section{PRIMARY PREVENTION}

Primary prevention must enable the identification and isolation of those factors, whose reduced exposure by individuals and by the general population, prevent the development of the disease, or if it ultimately the disease does so, prevent its severity.

There are three main risk factors: smoking, inappropriate dietary habits and the lack of physical exercise, that contribute to the appearance of chronic diseases (cardiovascular diseases, diabetes type 2 and cancer) and that are responsible for $50 \%$ of the deaths worldwide. These three factors along with occupational exposure, that entails certain groups being exposed to higher concentrations of carcinogens than the general population, and environmental exposureconcentrations to which the general population is exposed and before which little or nothing can be done by individuals to control it- explain most of the cases of cancer within the population.

These damaging exposures are not randomly distributed, but the social position is clearly related to

Table 1. European Code against cancer (third revision)

Many aspects of general health can be improved and many cancer deaths prevented, if we adopt healthier lifestyles:

1. Do not smoke; if you smoke, stop doing so. If you fail to quit, do not smoke in the presence of non-smokers.

2. Avoid obesity.

3. Undertake some brisk, physical activity every day.

4. Increase your daily intake and variety of vegetables and fruits: eat at least five servings daily. Limit your intake of foods containing fats from animal sources.

5. If you drink alcohol, whether beer, wine or spirits, moderate your consumption to two drinks per day if you are a man or one drink per day if you are a woman.

6. Care must be taken to avoid excessive sun exposure. It is specifically important to protect children and adolescents. For individuals who have a tendency to burn in the sun, active protective measures must be taken throughout life.

7. Apply strictly regulations aimed at preventing any exposure to known cancer-causing substances. Follow all health and safety instructions on substances which may cause cancer. Follow advice of national radiation protection offices.

8. There are Public Health programmes which could prevent cancers developing or increase the probability that a cancer may be cured:

9. Women from 25 years of age should participate in cervical screening. This should be within programmes with quality control procedures in compliance with "European Guidelines for Quality Assurance in Cervical Screening".

10. Women from 50 years of age should participate in breast screening. This should be within programmes with quality control procedures in compliance with "European Guidelines for Quality Assurance in Mammography Screening”.

11. Men and women from 50 years of age should participate in colorectal screening. This should be within programmes with built-in quality assurance procedures.

12. Participate in vaccination programmes against hepatitis $B$ virus infection. 
the level of exposure, being the lower social positioned groups the ones that are mainly exposed to health damaging exposures.

\section{Smoking}

Smoking can be blamed for causing $87 \%$ of the deaths attributable to lung cancer. In all the individual models used to predict lung cancer risk, smoking is found to be the main factor. Furthermore it is also an essential factor in the development of esophageal, laryngeal and oral cancer, as about 80 to $90 \%$ of the cases are caused by smoking or by the combination of smoking and drinking. Around 25 to $30 \%$ of all cancer cases are related to smoking ${ }^{3-4}$. Spain is one of the European countries where the prevalence of smoking is higher. It has been observed that throughout the last 15-20 years the consumption has been reduced: in $198738 \%$ of the population smoked while in 2011 $31.6 \% \mathrm{did}^{6}$. The smoking rates for men have dropped since 1987 from $55 \%$ to $39.1 \%$ in 2011 . For women the rate has climbed from $23 \%$ in 1987 to $27.2 \%$ in 2001 and in 2003 the tendency changed and $24.6 \%$ of women smoked in 2011'.

As far as social groups are concerned, in 1987 over half of the male population smoked, and prevalence was higher among lower income groups (manual workers); among women, the habit was more extended among higher income groups (non-manual workers). Progressively, the smoking habit rates have dropped among men, especially in the higher income groups (non-manual workers), which entails growing social inequality. Women from more privileged groups increased substantially smoking until 1997, and afterwards they started to quit smoking quicker than other less privileged groups. Hence, in the 2006 survey the group with a higher prevalence for smoking was men from underprivileged groups, and followed by women from underprivileged groups. ${ }^{7}$

According to the European Code ${ }^{3-4}$, it has been proven that the biggest impact on the modification of smoking can be obtained when acting on social aspects rather than on individuals: forbidding all kind of direct and indirect advertising, banning smoking in public or closed places, placing effective warning labels on the packets, controlling the maximum nicotine and tar content of cigarettes, along with other measures for informing and discouraging smoking.

\section{Alcohol}

Alcohol consumption has been related to an increased risk of oral, pharyngeal, laryngeal, esophageal, liver, colorectal and breast cancer ${ }^{3,4,8}$. Alcohol use is also related to the risk of primary liver cancer, probably because of the development of hepatic cirrhosis. The increase of colorectal cancer risk is also related to the amount of alcohol consumed, independently of the type of drink. As breast cancer is concerned, an increase of the risk has also been perceived, although not significantly strong. The risk of esophageal cancer is reduced by $60 \%$ after 10 years or more since stopping drinking ${ }^{8-10}$. The use of alcohol combined with smoking multiplies the harmful effects of both, and an important increase in the risk of suffering respiratory and upper digestive tract cancers. The World Cancer Research Fund ${ }^{10}$ and the American Institute for Cancer Research (2007) ${ }^{9}$ advise to reduce the proportion of population that surpasses the alcohol consumption limits by a third every 10 years, in order to fight against chronic diseases. The recommendations are not to drink over two units a day for men, and one for women (about/around 10-15 ethanol grams). ${ }^{3-4}$

\section{Diet}

It is estimated that around $30 \%$ of the deaths caused by cancer are related to diet and nutrition ${ }^{3-4}$. Several epidemiologic studies point out a protective effect of consuming more fruits and vegetables for an important number of cancers, specially for esophageal, stomach, colon, rectal and pancreatic cancer ${ }^{3-4,10}$. Red meat and specially processed meats (meat that has been salt-cured, cured or smoked, or with additives or preservatives) are probable causes of certain cancers. High- fiber cereals and whole-grain have been related to lower risk of colorectal and digestive tract cancers. Vegetables and fruits have a great number of potential anti-cancer agents, with complementary and overlapped mechanisms of action. Therefore the intake of these products prevents and holds up the development of some types of cancer-10.

Another factor that is directly related with nutrition, due to excessive intake, is obesity, one of the leading preventable causes of morbidity and mortality ${ }^{11}$. In particular, it increases the risk of diabetes, cardiovascular diseases and cancer. It is related to a higher risk of colon, breast (after menopause), endometrial, kidney and esophageal (adenocarcinoma) cancer ${ }^{9-11}$. Overweight is also related to other types of cancer but its effect on the risk is smaller ${ }^{9-11}$.

From 1987 to 2010, the prevalence of obesity has been doubled within the Spanish population. There are social inequalities not only among men but also among women. Among men, group inequalities have not been significantly increased; in $200616 \%$ of the men that came from lower-income groups were obese, as opposed to $14 \%$ of men from more privileged 
groups. Among women inequalities have grown, especially because of the obesity increase among nonmanual workers compared to the rest of the population. In 1987, 5.8\% of women from lower income groups were obese while this percentage has grown to $17.9 \%$ in 2006. In $19875.7 \%$ of women from higher income groups were obese while this percentage has grown to $9.7 \%$ in 2006. Women of underprivileged groups (manual workers) present the higher prevalence of obesity ${ }^{12}$.

\section{Physical exercise}

There is evidence that doing some exercise regularly is related to reducing the risk of colon, breast, endometrial and prostate cancer ${ }^{3-4}$. The protective effect of physical exercise over the risk of cancer grows with the level of exercise - the more, the better- but such recommendation should be modified for people with cardiovascular diseases ${ }^{3-4}$.For some types of cancer, the preventive effect of regular physical exercise seems to be independent of the body mass index ${ }^{3-4}$, ${ }^{10}$. Physical activity can be done as leisure taking part in different outdoor activities or in specialized indoor facilities, but it can also be done during everyday life, for instance by not using motor vehicles, changing our transport habits for walking or cycling or combining one of them with the use of public transport ${ }^{3,13}$.

However, physical exercise depends on the availability of parks or recreational areas near the primary residence and this contributes to the differences that can be found in the level of activity from one group to another ${ }^{14}$. Many studies have found that in poorer areas there is a significantly lower number of recreational areas, parks, sport facilities, rail trails, cycle lanes than in wealthier areas. Furthermore in lower income neighborhoods there is more traffic of heavy goods vehicles, less street light, sidewalks and there are no traffic calming measures, all of them, barriers that complicate doing exercise. Moreover, it has also been remarked that even when there are nearby facilities, the cost, the distance to them and the transportation availability affects the access and use of these services by the lower-income population. It has been proven that neighborhood planning contributes to be more physically active when there is good access to parks, availability of gyms, local shops in the neighborhood, nearby working places, schools, and leisure centers ${ }^{14}$.

Since 1987 physical exercise has suffered an increase in Spain, both among men and women. Women do less physical activity, and in many cases, there is still a high rate, over $30 \%$ that declare themselves as sedentary ${ }^{15}$.

\section{Environmental and occupational exposure}

Currently, many carcinogenic natural and artificial sources have been identified. The exposure to occupational or environmental carcinogens, could influence the development of cancers. The control of the prevalence and the level of exposure to occupational and environmental carcinogens -by means of general prevention measures- has historically played a more important role in cancer prevention than personal protection measures.

The types of cancer that have been most commonly related, with increasing evidence, to occupational exposures are lung cancer, bladder cancer, mesothelioma, laryngeal cancer, leukemia, liver angiosarcoma, nose and nasal cavity cancer and skin cancer (not melanoma) $)^{3-4}$.

Most of the occupational carcinogens have been assessed by the International Agency for Research on Cancer (IARC Lyon, France). It has been estimated that in the 90's around 32 million workers $(23 \%)$ of the European Union had been exposed to levels of carcinogens above the upper limits.

Environmental exposures refer to exposures of the general population that cannot be directly controlled by individuals ${ }^{3-4}$. Air pollution, drinking water contaminants, passive smoking, indoor radon, exposure to sunlight, contaminants in the food as pesticides, dioxins and environmental estrogens, chemical products from industrial emissions among other, are all included. Exposure can affect the general population, as in the case of environmental air pollution, or could be more specific and only affect groups that for example lived around a polluting industry. These types of exposure have been related to certain types of cancer, including lung cancer, bladder cancer, leukemia and skin cancer. The impact of several types of carcinogenic environmental exposure such as exposure to arsenic present in drinking water has not been quantified, although exposure to arsenic only affects certain populations. Air pollutants such as fine particles have been related in several studies to a slightly increased risk of lung cancer, even in urban areas where currently exposure has been reduced. Evidence of the effect of exposure to widespread agents such as the subproducts of the water disinfection, are not yet concluding. Common environmental agents, to which many people are exposed during long periods of time, such as passive smoking or air pollution, even if we consider that they have a small effect on an increased risk for certain types of cancer, could be behind the origin of many thousands of cases every year in Spain and in the European Union. 


\section{Infections}

Currently, around $10 \%$ of cancer cases in Europe are attributable to persistent infections caused by virus, bacteria or parasites. These infections are mainly implied in the development of four types of cancer: cervical cancer, kidney cancer, stomach cancer and hemo-lymphopoietic tumors ${ }^{3-4}$. In the European Union, around 25.000 women develop cervical cancer every year and 30.000 new kidney cancer cases are diagnosed. Helicobacter pylori (HP) is related to a risk 6 times higher of suffering non-cardia gastric cancer, which means that of the 78.000 new gastric cancer cases discovered every year $65 \%$ are attributable to HP. The fourth group is that of hemo-lymphopoietic tumors (Non-Hodgkin lymphoma, different types of leukemia, etc.). There are 104.000 new cases reported yearly and it is suspected that some infectious agents, such as Epstein Barr virus, HIV or Human herpesvirus 8 , may play a very important role in their development.

Throughout the last 30 years the knowledge of how some infectious agents play a role in the etiology of several types of cancer has been spread, especially after the major improvements achieved in the detection of markers of chronic infection. Therefore, antiviral and antibacterial treatments as well as vaccination programs represent an important tool against cancer $^{3-4}$.

\section{SECONDARY PREVENTION}

Many factors that may influence the development of cancer are still unknown, and others that are broadly known such as age or a family history of cancer, are unavoidable. Hence the need arises to early detect cancer, when it is in an early stage and it is possible to treat it by relatively easy means.

Secondary prevention or screening is most important during subclinical stages, entailing an earlier detection of cancer, even more so as screening methods grow more sensitive. Screening is an effective method for controlling cancer. Overall, the development of cancer is slow, with a direct effect of already discussed external factors on people at risk of having modified cells that could become cancer cells that grow with an unregulated, quickened pace. During the development of a tumor after the latency period (from the first exposure to the development of the cancer mutation), a more or less long preclinical stage (asymptomatic) is identified and it can last from a few months to several years, before the clinical stage, where the cancer finally reveals its symptoms. It is in this pre- clinical stage when screening can be implemented for some diseases.

The benefits of screening are obtained because of an early diagnosis, which together with the correspondent appropriate actions, will allow an improved prognosis for those patients diagnosed with the disease. In the population were screening is carried out mortality will be reduced because of this reason ${ }^{16-20}$. Furthermore, treatment alternatives can be less aggressive and people that take part in it feel more confident about that particular disease.

Screening also entails a series of disadvantages and risks. Part of the diagnosed lesions could never turn into an aggressive type, therefore an overdiagnosis and overtreatment effect can occur because of screening. Sometimes false positive $e^{21}$ and false negative results can occur and people will feel falsely reassured, therefore delaying the diagnosis of cancer or implying the appearance of cancer between two tests ${ }^{22}$. Moreover, false positive results may give rise to unnecessary diagnosis tests.

Because of all this it is fundamental to fulfill a serious of requirements which will grant a positive relationship between benefits and adverse reactions ${ }^{23-24}$. (Table 2)

Screening must be a continuous process and not a punctual test $\mathrm{t}^{25}$.The result of a single screening test only allows the differentiation between individuals at a higher risk of suffering the problem and, therefore, it will always need a diagnostic confirmation. The WHO considers that cancer control policies must be applied in all countries and that screening should be framed in disease control programmes.

Screening tests must be carried out always within the frame of organized programmes that ensure a quality assurance at all levels, and easing the appropriate information of the benefits and risks ${ }^{26}$.

A population screening program is framed within a institutional policy, and must be systematically offered to all the target population, with a clearly defined methodology and an adequate continuous assessment of the quality and of its results ${ }^{27-28}$. Screening must not be recommended because of individual requests, because quality, methodology and frequency cannot be guaranteed and the previously discussed side effects could arise.

One of the principles on which population screening programmes are based is equity, and avoiding socio-economic inequalities. Sometimes that principle needs to be approached in a complex way mainly if specific population groups, such as the imprisoned population, want to be included. This requires the combination of population criteria (inviting a target 
group that periodically lives in a territory), with the mobility of this group. Nevertheless, it is one of the implicit objectives of the screening programs, to ensure the access of all the population.

Few tumors are currently considered firm candidates to be included in a population screening program, because it is not only important that the tumor is relevant and common, but it is necessary to have appropriate tests that detect them in early stages so that it will have an impact in mortality rates.

Currently only three types of cancer clearly fulfill the appropriate requirements to recommend population screening. Both in the European Union ${ }^{29}$ and in Spain, cancer strategies of the National Health System (NHS) ${ }^{30}$ have established clear indications for the early diagnosis of these tumors.

Breast cancer screening should only be done in women between the ages of 50 and 69 , by means of a mammography, every two years. Currently digital mammography is being included in this kind of programs.

Screening for colorectal cancer is recommended for men and women over the age of 50 . Nowadays, there are several tests that have proved to be appropriate diagnosis techniques. In Spain the most common test is the fecal occult blood test every two years.

Screening for cervical cancer is also recommended. The most widespread test is the cervical and vaginal cytology. Currently there are on-going studies that propose different tests based on the relation of cervical cancer with persistent infections with high viral load of human papillomavirus.

In Europe, cancer screening programs have been introduced following the European recommendations 31. In Spain healthcare authorities from the different Autonomous Communities offer population breast cancer programmes. Most Autonomous Communities also include programmes for the early detection of cervical cancer. More recently, colorectal cancer ${ }^{32-33}$ screening programmes, for men and women aged between 50 and 69 , are being introduced.

There is no evidence for recommending screening for the early detection of other tumors. Nevertheless, there are being several studies conducted for studying the benefit to the general population of screening certain frequent types of cancer such as prostate cancer and lung cancer, but no conclusions have been brought out yet. (Table 3)

\section{What is being done within the penitentiary context to prevent cancer?}

Different types of interventions to prevent cancer are being carried out in the penitentiary facilities in our country, as several publications can give proof of.

In a study that assessed the mortality in Spanish prisons between 1994 and 2009, it was pointed out that the epidemiologic patterns seem to be changing. During the first period of the study HIV was the major cause of death, while during the second part of the period, cardiovascular diseases lead the causes of dea$\mathrm{th}^{34}$. Cancer is not an outstanding health problem in prisons, although its prevention is important at any point.

A thorough bibliographic search was performed with the aim of knowing the situation of the preventive actions focused on cancer carried out in the Spanish correctional facilities. A free search was done in $\mathrm{Me}-$ dline using the key words "prisons AND Spain AND (prevention OR cancer OR”). With “prevention” 26 publications were found related to tuberculosis, HIV

Table 2. Criteria for implementing a screening program.

Target disease
- It must be common and severe, in order to be considered a social problem by part of the population and thus the program will be well tolerated.

- Its clinical course must be well known and its pre-symptomatic stage must be clearly defined.

- Treatment in an early pre-symptomatic stage must reduce mortality or serious complications (if any) in a more noticeable way than treatment after the appearance of symptoms.
- High prevalence of the disease among the population.

- There must be inclination to involvement.

- There must be demographic information of the population in order to correctly schedule the necessary resources to carry out the screening program.

Diagnostic tests to be used - Well tolerated by general population, even if it could endanger participation.

- It must be reproducible and valid. 
or drugs. With "cancer", 2 publications were found that studied the prevalence of Human Papillomavirus; one of this publications adverted that $27.1 \%$ of women inmates had positive testing and that the related factors were to be young and smoking. It was also found that it was closely related to being infected with $\mathrm{HIV}^{35}$. The other publication revealed a prevalence of HPV infection of $46 \%{ }^{36}$. A more specific search was done in the Spanish journal of prison health (Revista de Sanidad Penitencia) using the key word cancer, and 21 publications were found. Amore in-depth evaluation showed that only 6 of them were related with vaccine-preventable diseases whose impaired management can lead to the development of cancer such as hepatitis C, B or HPV as well as their current status and clinical management.

A search has been done for each risk factor; for smoking only one intervention was found, which focused on helping female inmates to quit smoking. $81.2 \%$ of women who answered to a previous questionnaire were smokers and had increased the number of cigarettes smoked since their imprisonment. $65 \%$ reported that they had previously stopped smoking.
$22 \%$ of the women that participated continued without smoking one year later. ${ }^{37}$

If the word alcohol was introduced in the search tool, 65 publications were found, albeit there were no specific group interventions for reducing its consumption, but more general interventions ${ }^{38}$. As far as nutrition is concerned, two publications were found that show campaigns for enhancing the inmates' diet, reducing the ingestion of fat in order to have more heart- healthy ${ }^{39}$ diets and adapting them to convicted people with diabetes ${ }^{40}$. Regarding physical activity a publication reveals an intervention in a prison where a positive adherence to the program was observed and the participants were satisfied ${ }^{41}$. Summarizing, some experiences demonstrate that it is possible to introduce changes focused on enhancing the general health and with positive results as far as satisfaction of participants is concerned. Even though we cannot conclude if these measures are widespread within prisons, we can think that many of these interventions are scarcely documented or its results published. Hence these programs could improve if more publications were made, because of a larger number of professio-

Table 3. Recommendations on cancer screening

\begin{tabular}{|c|c|c|}
\hline & European Union & Cancer Strategy of the National Health System \\
\hline $\begin{array}{l}\text { Breast } \\
\text { Cancer } \\
\text { Screening }\end{array}$ & $\begin{array}{l}\text { Mammography screening for } \\
\text { breast cancer in women aged } 50 \text { - } \\
69 \text { in accordance with «European } \\
\text { guidelines on quality assurance in } \\
\text { mammography». }\end{array}$ & $\begin{array}{l}\text { - Continue with population breast cancer screening programmes } \\
\text { with the following principles: } \\
\text { - Target population: age between } 50 \text { and } 69 \text {. } \\
\text { - Screening test: mammography. } \\
\text { - Frequency of screening: every } 2 \text { years. } \\
\text { - Familial risk assessment will be promoted, including the genetic } \\
\text { study in people with features suggestive of hereditary cancer. }\end{array}$ \\
\hline $\begin{array}{l}\text { Colorectal } \\
\text { Cancer } \\
\text { Screening }\end{array}$ & $\begin{array}{l}\text { Fecal occult blood screening for } \\
\text { colorectal cancer in men and } \\
\text { women age } 50-74\end{array}$ & $\begin{array}{l}\text { - Implement colorectal cancer screening programmes for mid- } \\
\text { low risk population: } \\
\text { - Target population: age between } 50 \text { and } 69 \text {, in an initial stage. } \\
\text { - Screening test: fecal occult blood testing (FOBT). } \\
\text { - Frequency of screening: Every } 2 \text { years. } \\
\text { - Specific/dedicated programmes for people with high risk will } \\
\text { be implemented. }\end{array}$ \\
\hline $\begin{array}{l}\text { Cervical } \\
\text { Cancer } \\
\text { Screening }\end{array}$ & $\begin{array}{l}\text { Pap smear screening for cervical } \\
\text { abnormalities starting at the latest } \\
\text { by the age of } 30 \text { and definitely not } \\
\text { before the age of } 20 \text {. }\end{array}$ & $\begin{array}{l}\text { - Optimize the way of conducting cytological tests in mid-low } \\
\text { cancer risk women based on the following criteria: } \\
\text { - Target population: Women with no symptoms that are or } \\
\text { have been sexually active, aged between } 25 \text { and } 65 \text {. } \\
\text { - Screening test: cervical cytology. } \\
\text { - Screening intervals: The first two cytological tests will be } \\
\text { done with a difference of one year. In case of negative results, } \\
\text { the frequency will be of one cytological test every } 3 \text { - } 5 \text { years. } \\
\text { - Guaranteeing a specific follow-up for women with high risk of } \\
\text { suffering cervical cancer. }\end{array}$ \\
\hline
\end{tabular}


nals contributing to the results. However, and as it can be seen in some programs and health promotion related publications, it is not necessary to carry out highly fragmented interventions regarding risk factors. The most successful interventions are those with a more comprehensive approach, with participative discussions about the objectives to pursue, and that include not only behavioral changes but also an appropriate environment for these changes to happen, such as enhanced diets or smoke-free environments ${ }^{42}$.

\section{CONCLUSION}

The reduction of certain risk factors such as smoking, drinking, as well as controlling the risks of environmental and occupational carcinogens, together with a healthy balanced diet along with physical exercise, could influence an important reduction of the most common types of cancer.

Early diagnosis of some tumors could also contribute to control this disease, especially to reduce its mortality. Nevertheless, early detection should only be recommended in those types of cancer where the benefits of screening outweigh the risks. Currently it is only recommended for breast, colorectal and cervical cancer.

It is estimated that $80-90 \%$ of cancer cases could be preventable with public health policies. But the benefit of these preventive policies will be socially shared, only if strategies that benefit all social groups, equally and not only focused on disadvantaged groups, are developed.

\section{CORRESPONDENCE}

Lola Salas Trejo

Jefa Servicio Plan Oncológico

Direcció General Salut Pública. Conselleria Sanitat.

Av. Catalunya, 21. 46020 Valencia

salas_dol@gva.es

\section{BIBLIOGRAPHIC REFERENCES}

1. Cabanes Domenech, A, Pérez-Gómez B, Aragonés N, Pollán M, López-Abente G. La situación del cáncer en España, 1975-2006. Madrid: Instituto de Salud Carlos III; 2009.

2. Sánchez MJ, Payer T, De Angelis R, Larrañaga N, Capocaccia R, Martínez C, for the CIBERESP
Working Group. Cancer incidence and mortality in Spain: estimates and projections for the period 1981-2012. Ann Oncol. 2010; 21 Suppl. 3: iii30-6.

3. Boyle P, Autier P, Bartelink H, Baselga J, Boffetta P, Burn J, et al. European Code Against Cancer and scientific justification: third version (2003). Annals of Oncology 2003; 14: 973-1005.

4. Martín-Moreno JM. El código europeo contra el cáncer. Tercera revisión (2003): Insistiendo y avanzando en la prevención del cáncer. Rev esp salud pública 2003; 77: 673-9.

5. Etzel CJ, Bach PB. Estimating individual risk for lung cancer. Semin Resp Crit Care Med 2011; 32: 3-9.

6. Ministerio de Sanidad, Servicios Sociales e Igualdad [Internet]. Madrid: Ministerio de Sanidad; c2011-2013 [actualizado 2013; citado 2013 feb 01]. Encuesta Nacional de Salud de 2001, 2003, 2007 y 2011 [1 screen]. Disponible en: http://www.msssi.gob.es/estadEstudios/estadisticas/encuestaNacional/home.htm

7. Ods-ciberesp.es [Internet]. Madrid: Observatorio de Desigualdades en la Salud; c2012 [actualizada 2012; citado 2013 feb 01]. Disponible en: http:// www.ods-ciberesp.es/id-conductas/consumo-detabaco-16-44-anos-1987-2006-genero-y-clasesocial.html\#Gráfico.

8. Key TJ, Schatzkin A, Willet WC, Allen NE, Spencer EA, Travis RC. Diet, nutrition and the prevention of cancer. Public Health Nut 2004: 7 (1A), 187-200.

9. Consulta Mixta OMS/FAO de Expertos en Régimen Alimentario, Nutrición y Prevención de Enfermedades Crónicas. Dieta, nutrición y prevención de enfermedades crónicas: informe de una Consulta Mixta de Expertos OMS/FAO. (OMS, Serie de Informes Técnicos; 916). OMS: Ginebra; 2003.

10. World Cancer Research Fund / American Institute for Cancer Research. Food, Nutrition, Physical Activity, and the Prevention of Cancer: a Global Perspective. Washington DC: AICR, 2007.

11. Bray GA. Medical consequences of obesity. J Clin Endocrinol Metab 2004; 89: 2583-9.

12. Ods-ciberesp.es [Internet]. Madrid: Observatorio de Desigualdades en la Salud; c2012 [actualizada 2012; citado 2013 feb 01]. Disponible en: www. ods-ciberesp.es/id-conductas/obesidad-19872006-genero-y-clase-social.html

13. Physical Activity Guidelines for Americans. Washington, DC: US Department of Health and Human Services; 2008. 
14. Ballester F, Peiró R. Transporte, medio ambiente y salud. Informe SESPAS 2008 Gac Sanit. 2008; 22 Suppl 1: 53-64.

15. Regidor E, Gutiérrez-Fisac JL, de los Santos Ichaso M, Fernández E. Trends in principal cancer risk factors in Spain. Ann Oncol. 2010 May; 21 Suppl 3: iii37-42.

16. Nyström L, Andersson I, Bjurstam N. 2002. Long-term effects of mammography screening: updated overview of the Swedish randomised trials. Lancet. Mar 16; 359(9310): 909-19.

17. Heresbach D, Manfredi S, D’halluin PN. Review in depth and meta-analysis of controlled trials on colorectal cancer screening by faecal occult blood test. Eur J Gastroenterol Hepatol. 2006; 18: 427-33.

18. Hewitson P, Glasziou P, Irwig L. Screening for colorectal cancer using the faecal occult blood test, Hemoccult. Cochrane Database Syst Rev. 2007; 1:CD001216.

19. Mandel JS, Church TR, Ederer F, Bond JH. Colorectal cancer mortality: Effectiveness of biennial screening for fecal occult blood. J Natl Cancer Inst. 1999; 91: 434-7.

20. Ascunce N, Moreno-Iribas C, Barcos A, Ardanaz E, Ederra M, Castilla J, et al. Changes in breast cancer mortality in Navarre (Spain) after introduction of a screening programme. J Med Screen. 2007; 14: 14-20.

21. Roman R, Sala M, Salas D, Ascunce N, Zubizarreta $\mathrm{R}$, Castells X. Effect of protocol-related variables and women's characteristics on the cumulative false-positive risk in breast cancer screening. Ann Oncol. 2012; 23: 104-11.

22. Domingo L, Sala M, Servitja S, Corominas JM, Ferrer F, Martínez J, et al. Phenotypic characterization and risk factors for interval breast cancers in a population- Based breast cancer screening program in Barcelona, Spain. Cancer Causes Control. 2010; 21: 1155-64.

23. UK Screening Portal [Internet]. London: UK National Screening Committee. Policy Review Process. Programme appraisal criteria. Criteria for appraising the viability, effectiveness and appropriateness of a screening programme; c2009-13 [actualizado 2013 feb 25; citado 2013 feb 20]. Disponible en: http://www.screening.nhs.uk/criteria

24. Cerdá Mota T, Ascunce Elizaga N. Implantación y Evaluación de Programas Poblacionales de Cribado. $3^{a}$ Monografía de la Sociedad Española de Epidemiología. Madrid: EMISA; 2006.

25. Wilson JM, Jungner G. Principles and practice of screening for disease. Public Health Papers. Ginebra: World Health Organization; 1968.
26. Wald NJ. The definition of screening. J Med Screen 2001; 8: 1.

27. Perry N, Broeders M, de Wolf C, editors. European Guidelines for Quality Assurance in Breast Cancer Screening and Diagnosis. 4th ed. Luxembourg: Office for Official Publications of the European Communities; 2006.

28. Segnan N, Patnick J, von Karsa L. European guidelines for quality assurance in colorectal cancer screening and diagnosis. 1st ed. Luxembourg: Office for Official Publications of the European Communities; 2010.

29. Council of the European Union. Council recommendation of 2 December 2003 on cancer screening. Official Journal of the European Union. 2003; 878: 34-8.

30. Ministerio de Sanidad y Consumo. Estrategias de cáncer del sistema nacional de salud. Madrid: Ministerio de Sanidad y Consumo; 2009.

31. Von Karsa L, Anttila A, Ronco G, Ponti A, Malila N, Arbyn M, et al. Cancer screening in the European Union. Report on the Implementation of the Council Recommendation on cancer screening - First Report. European Commission, 2008.

32. Cribadocancer.org [Internet]. Barcelona: Programas de detección precoz de cáncer en España; c2009-13 [actualizado 2013 feb 26; citado 2013 feb 20]. Disponible en: http://www.cribadocancer.org/

33. Ascunce N, Salas D, Zubizarreta R. Cancer screening in Spain. Ann Oncol.; 21 (3): 43-51.

34. García-Guerrero J, Vera-Remartínez EJ, Planelles Ramos MV. Causas y tendencias de mortalidad en las prisiones españolas. Rev Esp Salud Pública 2011; 85(3): 245-55.

35. González C, Canals J, Ortiz M, Muñoz L, Torres M, García-Saiz A, Del Amo J. Prevalencia y determinantes de alto riesgo de infección por papilomavirus humano y citologia cervical anormal en mujeres prisioneras. Epidemiol Infect 2008; 136(2): 215-21.

36. de Sanjosé S, Valls I, Paz Cañadas M, Lloveras B, Quintana MJ, Shah KV, Bosch FX. Infecciones por Papiloma virus humano y virus de la inmunodeficiencia como factor de riesgo para cáncer de cerviz en mujeres en prisión. Med Clin (Barc). 2000 Jun 17; 115(3): 81-4.

37. C Yagüe-Olmos, MI Cabello-Vázquez. Programa de deshabituación tabáquica para internos y trabajadores de un centro penitenciario Rev Esp Sanid Penit 2008; 10: 57-64.

38. F Herraiz Gonzalo. Programa de intervención psicoeducativo en el departamento de psiquiatría 
del centro penitenciario de hombres de Barcelona. Rev. Esp. Sanid. Penit. 1999; 2: 6-15.

39. Minchón Hernando A, Domínguez Zamorano JA, Gil Delgado y. Educación para la salud en centros penitenciarios: evaluación de una experiencia en personas con diabetes. Rev Esp Sanid Penit 2009; 11: 73-9.

40. Gil-Delgado Y, Domínguez-Zamorano JA, Martínez-Sánchez-Suárez E. Valoración de los beneficios para la salud conseguidos mediante un programa nutricional dirigido a internos con factores de riesgo cardiovascular del Centro Penitenciario de Huelva. Rev Esp Sanid Penit 2011; 13: 75-83.

41. Pérez F. Programa de adherencia al ejercicio físico, dirigido a usuarios de Programas de Mantenimiento con Metadona (PMM) Rev Esp Sanid Penit 2002; 4: 114-7.

42. Merino B. Las prisiones: una nueva oportunidad para la Salud Editorial Rev Esp Sanid Penit 2005; 7: 1-3. 